\title{
Microstructural control for ultrafine-grained non-oxide structural ceramics
}

\author{
Mikinori HOTTA ${ }^{\dagger}$ \\ Advanced Manufacturing Research Institute, National Institute of Advanced Industrial Science and Technology (AIST), \\ 2266-98 Shimo-shidami, Moriyama-ku, Nagoya 463-8560, Japan
}

\begin{abstract}
Ultrafine-grained non-oxide ceramics were prepared by combining the synthesis technology for fine-grained starting powders and the rapid sintering technology for spark plasma sintering (SPS); the two technologies were combined for obtaining ceramics with improved heat and corrosion resistance and improved mechanical properties. Hollow spherical Ca- $\alpha$ SiAlON powders composed of nanosized particles were synthesized by carbothermal reduction-nitridation of a $\mathrm{SiO}_{2}-\mathrm{Al}_{2} \mathrm{O}_{3}-\mathrm{CaCO}_{3}$ powder mixture. Using the Ca- $\alpha$ SiAION powder, dense $\mathrm{Ca}-\alpha$ SiAION nanoceramics and porous $\mathrm{Ca}-\alpha$ SiAION ceramics with excellent mechanical properties and high heat and corrosion resistance were fabricated by the SPS technique. Ultrafine-grained $\mathrm{Si}_{3} \mathrm{~N}_{4}$ and $\mathrm{SiC}$ ceramics were prepared from fine-grained $\mathrm{Si}_{3} \mathrm{~N}_{4}$ and $\mathrm{SiC}$ powders by SPS. The densification of cubic-BN-dispersed ceramics composites was achieved without the phase transformation of cubic BN to low-hardness hexagonal BN, at a moderate pressure by the SPS technique.
\end{abstract}

(C2012 The Ceramic Society of Japan. All rights reserved.

Key-words : Microstructural control, Ultrafine grain, Powder synthesis, Spark plasma sintering, SiAION, Silicon nitride, Silicon carbide, Cubic boron nitride

\section{Introduction}

Structural ceramics are expected have uses in various fields such as manufacturing, energy, and environmental sciences and to contribute to energy saving and a reduction of the environmental load. Accordingly, the author considers it necessary to further improve the thermal, mechanical, and chemical properties of structural ceramics by means of microstructural development by using ultrafine grains. Among the structural ceramics, nonoxide ceramics have high hardness, high elastic modulus, and excellent heat resistance. In the present work, using a combination of a synthesis technology for fine-grained raw powders and a rapid sintering technology, ultrafine-grained non-oxide ceramics were developed.

\subsection{SiAION}

SiAlON ceramics have high hardness, and excellent corrosion and oxidation resistance at high temperatures, which makes them useful for engineering applications. $\alpha$-SiAlON is a solid solution with the $\alpha-\mathrm{Si}_{3} \mathrm{~N}_{4}$ crystal structure in which some Si and $\mathrm{N}$ atoms are replaced by $\mathrm{Al}$ and $\mathrm{O}$ atoms, and some metal cations $\mathrm{M}$, such as those of $\mathrm{Li}, \mathrm{Mg}, \mathrm{Ca}, \mathrm{Y}$ or most rare-earth elements, are incorporated as a stabilizer. ${ }^{1)} \alpha$-SiAlON ceramics are generally produced through liquid-phase sintering of $\mathrm{Si}_{3} \mathrm{~N}_{4}-\mathrm{AlN}-\mathrm{M}_{x} \mathrm{O}_{y}$ powder mixtures. ${ }^{2)}$ The high-temperature strength and corrosion resistance of $\alpha$-SiAlON ceramics are degraded by a residual glass phase at the grain boundary resulting from the liquid-phase sintering. ${ }^{3)}$ Furthermore, it is difficult to achieve a uniform composition, and form homogeneous and fine-grained microstructure from the powder mixtures of $\mathrm{Si}_{3} \mathrm{~N}_{4}-\mathrm{AlN}-\mathrm{M}_{x} \mathrm{O}_{y}$. Consequently, the development of high-purity and fine-grained $\alpha$-SiAlON powders is necessary to improve the reliability of $\alpha$-SiAlON

\footnotetext{
Corresponding author: M. Hotta; E-mail: mikinori-hotta@aist. go.jp
}

ceramics. $\alpha$-SiAlON powders have been synthesized through carbothermal reduction-nitridation $(\mathrm{CRN})$ of $\mathrm{SiO}_{2}-\mathrm{Al}_{2} \mathrm{O}_{3}-\mathrm{M}_{x} \mathrm{O}_{y}$ system. There are reports that $\alpha$-SiAlON powder can be made by heating powder mixtures of $\mathrm{SiO}_{2}-\mathrm{Al}_{2} \mathrm{O}_{3}-\left(\mathrm{Ca}\right.$ - or Y-) oxide, ${ }^{4,5)}$ talc $\left(\mathrm{Mg}_{3} \mathrm{Si}_{4} \mathrm{O}_{10}(\mathrm{OH})_{2}\right)$-halloysite $\left(\mathrm{Al}_{2} \mathrm{Si}_{2} \mathrm{O}_{5}(\mathrm{OH})_{4}\right)$ clay minerals, ${ }^{6,7)}$ clay-metal compounds, ${ }^{8)}$ slag-clay mixtures, ${ }^{9), 10)}$ or zeolite $^{11)}$ with carbon in flowing $\mathrm{N}_{2}$ gas. Among $\alpha$-SiAlON ceramics, $\mathrm{Ca}-\alpha$ SiAlON has received considerable attention because of the low cost of the raw material (a $\mathrm{Ca}$ compound), high cation $(\mathrm{Ca})$ solubility in the $\alpha$-SiAlON lattice, thus a low residual glass phase, and good thermal stability. ${ }^{12)}$ However, rare-earth doped $\alpha$-SiAlON has largely fabricated to enhance oxidation and corrosion resistance of $\alpha$-SiAlON. ${ }^{13)-18)}$

\subsection{Silicon nitride}

Silicon nitride $\left(\mathrm{Si}_{3} \mathrm{~N}_{4}\right)$ ceramics are one of the most promising materials for structural applications at high temperatures. However, $\mathrm{Si}_{3} \mathrm{~N}_{4}$ is very difficult to densify by solid-phase sintering because of its strong covalent bonding and the low self-diffusion coefficients of $\mathrm{Si}$ and $\mathrm{N}$. The conventional method for the densification of $\mathrm{Si}_{3} \mathrm{~N}_{4}$ ceramics generally involves liquidphase sintering with metal oxide additives. In contrast, the grain boundary phase derived from the sintering additives degrades the mechanical properties and oxidation and corrosion resistance at high temperatures. ${ }^{19)}$ Therefore, for improving these properties, the amount of sintering additives used for the fabrication of dense $\mathrm{Si}_{3} \mathrm{~N}_{4}$ ceramics should be minimized.

\subsection{Silicon carbide}

Silicon carbide $(\mathrm{SiC})$ ceramics have many attractive properties such as relatively low density, high hardness, excellent mechanical strength at high temperatures, and good thermal stability. However, it is difficult to densify a $\mathrm{SiC}$ powder without using sintering additives because of its strong covalent bonding; the same is true for $\mathrm{Si}_{3} \mathrm{~N}_{4}$. The typical densification technique for 
$\mathrm{SiC}$ is solid-phase sintering with $\mathrm{B}-\mathrm{C}$ additives,${ }^{20)}$ or liquid-phase sintering with metal oxide additives such as $\mathrm{Al}_{2} \mathrm{O}_{3}$ and $\mathrm{Y}_{2} \mathrm{O}_{3}{ }^{21}$ ) The merit of using liquid-phase sintering for $\mathrm{SiC}$ ceramics is that homogeneous and fine-grained microstructures can be formed, unlike solid-phase sintering, because of the lower sintering temperature and the presence of the liquid phase. ${ }^{22)}$ The residual glass phase significantly affects the high-temperature mechanical properties of $\mathrm{SiC}$ ceramics. ${ }^{23)}$

\subsection{Cubic boron nitride}

Cubic boron nitride (cBN) has the highest hardness and thermal conductivity next to diamond, and it is more thermally stable and less reactive with iron than diamond. Because of these properties, cBN is used for fabricating cutting tools for machining hardened steel and cast iron. ${ }^{24)}$ However, it is difficult to obtain fully dense cBN materials because of the strong covalent bonding and the low self-diffusion coefficients of $\mathrm{B}$ and $\mathrm{N}$. Moreover, cBN transforms into low-hardness hexagonal BN $(\mathrm{hBN})$ at high temperatures. ${ }^{25)-27)}$ Hence, high-density $\mathrm{cBN}$ bodies for cutting tools have usually been produced by sintering under an ultrahigh pressure (greater than $5 \mathrm{GPa}$ ) with various types of additives, such as $\mathrm{Al}, \mathrm{Ti}$, TiN, and $\mathrm{TiC}^{28)-31)}$ However, an economical sintering process involving a moderate pressure of less than $100 \mathrm{MPa}$ is required for preparing cBN-based materials that can be used for fabricating cutting tools for a wide range of applications. ${ }^{32)}$ While $\mathrm{cBN}$ and common ceramics such as $\mathrm{Al}_{2} \mathrm{O}_{3}, \mathrm{TiN}, \mathrm{Si}_{3} \mathrm{~N}_{4}$, and $\mathrm{SiAlON}$ possess high hardness and excellent thermal stability, their fracture toughness is lower than that of high-speed steels, hard metals, and cermets. Therefore, a combination of ceramics and $\mathrm{cBN}$ would be a promising material for cutting tools with high hardness and fracture toughness.

\subsection{Spark plasma sintering}

The spark plasma sintering (SPS) technique can be used for heating specimens rapidly because a pulsed direct current can pass through a graphite die and punch rod. ${ }^{33)}$ The advantage of the technique is grain growth can be inhibited during sintering since the total sintering process can be completed in a short time owing to the rapid heating. Moreover, hardly sinterable ceramics such as $\mathrm{Si}_{3} \mathrm{~N}_{4}, \mathrm{SiAlON}$, and $\mathrm{SiC}$, which are difficult to densify by using conventional sintering techniques, have been produced as fully dense ceramics using the SPS technique. ${ }^{34)-39)}$ The SPS technique is also called pulse electric current sintering (PECS), ${ }^{34)-36)}$ field-assisted sintering technique (FAST), ${ }^{37)}$ and plasma-assisted sintering (PAS) ${ }^{38)}$ because the generation of spark discharge and/or plasma during the process has not been verified. Many researchers have reported that fine-grained and fully dense ceramics can be produced by the SPS technique. ${ }^{35), 38), 39)}$ Moreover, the phase transformation of $\mathrm{cBN}$ to low-hardness hBN might be suppressed because of the short sintering time of the SPS process.

\section{Hollow spherical SiAION powders composed of nanosized particles ${ }^{40), 41)}$}

A $\mathrm{Ca}-\alpha$ SiAlON powder was synthesized by carbothermal reduction-nitridation $(\mathrm{CRN})$ of $\mathrm{SiO}_{2}-\mathrm{Al}_{2} \mathrm{O}_{3}-\mathrm{CaCO}_{3}$ and carbon powder mixtures. ${ }^{40), 41)}$ The proportions of the starting powders were calculated to obtain nominal $\mathrm{Ca}-\alpha \mathrm{SiAlON}$ compositions of $\mathrm{Ca}_{x} \mathrm{Si}_{12-3 x} \mathrm{Al}_{3 x} \mathrm{O}_{x} \mathrm{~N}_{16-x}$ (i.e., $x=n=m / 2$ in $\mathrm{M}_{x} \mathrm{Si}_{12-(m+n)^{-}}$ $\left.\mathrm{Al}_{m+n} \mathrm{O}_{n} \mathrm{~N}_{16-n}\right)$ with $x$ varying from 0.3 to 1.4 . The mixture of the starting powders was heated in a $\mathrm{N}_{2}$ gas flow using a horizontal electrical furnace. The residual carbon was removed by firing the powders at $700^{\circ} \mathrm{C}$ in air.

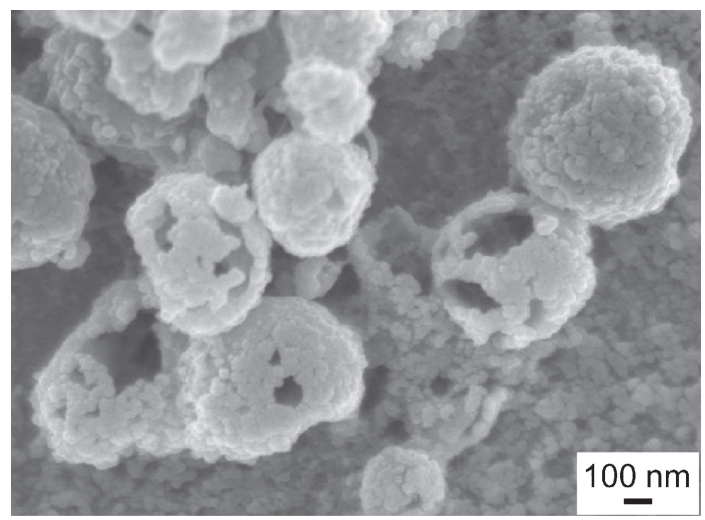

Fig. 1. SEM micrograph of $\mathrm{Ca}-\alpha \mathrm{SiAlON}$ powder prepared at $1450^{\circ} \mathrm{C}$ for $120 \mathrm{~min}$ for $x=1.0 .^{40}$ )

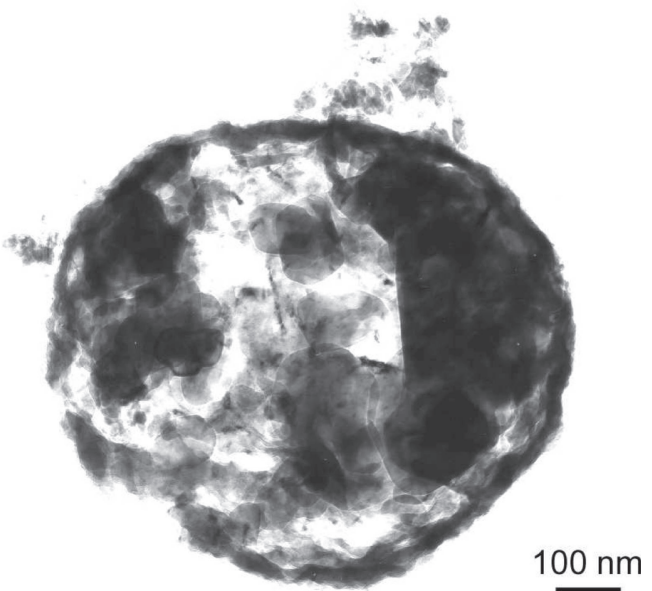

Fig. 2. TEM micrograph of $\mathrm{Ca}-\alpha \mathrm{SiAlON}$ powder prepared at $1450^{\circ} \mathrm{C}$ for $120 \min$ for $x=1.0 .{ }^{40}$ )

The crystalline phases appearing in the final specimens after heating at $1450^{\circ} \mathrm{C}$ for $120 \mathrm{~min}$ were $\mathrm{Ca}-\alpha$ SiAlON, $\beta$-SiAlON, and AlN for all the compositions. The amount of the crystalline phases depended on the starting composition. The maximum amount of $\alpha$-SiAlON was greater than 85 mass $\%$ for $x=1.0$ with AlN as a minor phase. The synthesized $\mathrm{Ca}-\alpha$ SiAlON powders showed a unique morphology of hollow spheres with diameters of $200-500 \mathrm{~nm}$ (Fig. 1). ${ }^{40}$ This morphology was basically observed for $x=0.5$ to 1.2. Further observations indicated that the $\mathrm{Ca}-\alpha$ SiAlON hollow spheres were composed of large numbers of nanosized particles having diameters of 10$30 \mathrm{~nm}$ and submicron-sized particles with a diameter of approximately $100 \mathrm{~nm}$ (Fig. 2) ${ }^{40)}$ The thickness of the shells of the $\mathrm{Ca}-\alpha$ SiAlON hollow spheres was around $50 \mathrm{~nm}$; therefore, these nanosized particles had very high surface areas. Moreover, the bonding between the nanosized particles in the $\mathrm{Ca}-\alpha$ SiAlON hollow spheres did not appear to be very strong because the hollow spheres could be broken down into nanosized particles by ultrasonic vibration. This particle morphology was significantly different from $\mathrm{Ca}-\alpha$ SiAlON powders synthesized by CRN under similar conditions but using different starting powders. ${ }^{4), 5)}$

\section{Investigation of formation mechanism of the SiAION hollow spheres composed of nanosized particles ${ }^{42)-44)}$}

The formation mechanism of the $\mathrm{Ca}-\alpha$ SiAlON hollow spheres composed of nanosized particles during the CRN process of the 
$\mathrm{SiO}-\mathrm{Al}_{2} \mathrm{O}_{3}-\mathrm{CaCO}_{3}$ powder mixtures was analyzed by investigating specimens obtained at various heating temperatures and various holding times. ${ }^{42)}$ A large number of solid spherical particles consisting of a $\mathrm{Si}-\mathrm{Al}-\mathrm{Ca}-\mathrm{O}$ amorphous phase were formed at the initial stage of CRN. Very fine particles were subsequently generated on the surface of these solid spheres, and the solid spheres gradually changed into hollow spheres with the progress of nitridation. When heating temperature was increased to $1450^{\circ} \mathrm{C}$, the $\mathrm{XRD}$ intensity of $\mathrm{Al}_{2} \mathrm{O}_{3}$ and the amorphous hump decreased, with oxynitride phases such as $\mathrm{Si}_{2} \mathrm{~N}_{2} \mathrm{O}$ and $\mathrm{SiAl}_{7} \mathrm{O}_{2} \mathrm{~N}_{7}$ now being detected. The intermediate phases were not observed in previous study when $\mathrm{Ca}-\alpha \mathrm{SiAlON}$ was synthesized through $\mathrm{CRN}$, where $\mathrm{SiO}_{2}$ and mullite were the only crystalline phases detected below $1250^{\circ} \mathrm{C}$. ${ }^{4), 5)}$ The formation of the $\mathrm{Ca}-\alpha$ SiAlON hollow spheres depends on the formation of the solid spherical particles from the $\mathrm{Si}-\mathrm{Al}-\mathrm{Ca}-\mathrm{O}$ liquid phase at the initial stage of the CRN. I guessed that an increase in the density and a decrease in the mass were the results of the conversion from the amorphous to crystalline $\alpha$-SiAlON, and that these results contributed to the formation of $\mathrm{Ca}-\alpha$ SiAlON hollow spheres composed of nanosized particles.

$\mathrm{Ca}-\alpha$ SiAlON powders were also prepared using $\mathrm{SiO}_{2}$ starting powders with different characteristics in terms of particle size, shape, and crystalline state in order to investigate the formation process of the $\mathrm{Ca}-\alpha$ SiAlON hollow spheres. $\left.{ }^{43}\right) \mathrm{Ca}-\alpha$ SiAlON hollow spheres composed of a large number of nanosized particles were formed through an intermediate $\mathrm{Si}-\mathrm{Al}-\mathrm{Ca}-\mathrm{O}$ liquid phase through a similar formation process, irrespective of the characteristics of the $\mathrm{SiO}_{2}$ starting powders used.

Furthermore, $\mathrm{Ca}-\alpha$ SiAlON powders were prepared using $\mathrm{SiO}_{2}-\mathrm{Al}_{2} \mathrm{O}_{3}-\mathrm{CaO}$ glass in order to find evidence for the $\mathrm{Ca}-\alpha$ SiAlON hollow spheres being derived from the $\mathrm{Si}-\mathrm{Al}-\mathrm{Ca}-\mathrm{O}$ liquid phase. ${ }^{44)}$ The particle morphology of the powders was the same as that of the $\mathrm{Ca}-\alpha$ SiAlON hollow spheres obtained from the $\mathrm{CRN}$ of $\mathrm{SiO}_{2}-\mathrm{Al}_{2} \mathrm{O}_{3}-\mathrm{CaCO}_{3}$ powder mixtures.

\section{Dense SiAION nanoceramics from nanosized Ca- $\alpha$ SiAION powder ${ }^{45)}$}

The prepared $\mathrm{Ca}-\alpha$ SiAlON hollow spheres composed of nanosized particles were ground to obtain a nanosized $\mathrm{Ca}-\alpha$ SiAlON starting powder. ${ }^{45}$ ) The powder was then sintered without using any sintering additive by spark plasma sintering (SPS) at $1700^{\circ} \mathrm{C}$ for $20 \mathrm{~min}$ in $\mathrm{N}_{2}$ under a uniaxial pressure of $30 \mathrm{MPa}$ at a heating rate of $100^{\circ} \mathrm{C} / \mathrm{min}$.

The phase content of the specimen sintered by SPS was almost the same as that in the starting powder. The sintered body had a full density of $99.2 \%$ in SPS, while no densification or significant grain growth occurred upon gas pressure sintering (GPS) of the nanosized $\mathrm{Ca}-\alpha \mathrm{SiAlON}$ powder. Crystallite sizes of the $\mathrm{Ca}-\alpha$ SiAlON starting powder and the body sintered by SPS were 27 and $34 \mathrm{~nm}$, respectively, as calculated by Scherrer's equation. The specimen had a bimodal microstructure composed of fine grains with diameters lesser than $50 \mathrm{~nm}$ and submicron-sized grains with diameters of 100-200 nm, as shown in Fig. 3. ${ }^{45)}$ The grain sizes were approximately the same as that of the starting powder, indicating that significant grain growth did not occur during the SPS process. Moreover, no residual glass phase was observed at the grain boundary of the $\mathrm{Ca}-\alpha$ SiAlON nanoceramics by high-resolution TEM. The Vickers hardness of the $\mathrm{Ca}-\alpha$ SiAlON nanoceramics was around $18 \mathrm{GPa}$, which was higher than that of typical $\mathrm{Si}_{3} \mathrm{~N}_{4}$ ceramics fabricated by GPS. The fracture toughness, approximately $3.2 \mathrm{MPa} \cdot \mathrm{m}^{1 / 2}$, was slightly lower than that of the $\mathrm{Si}_{3} \mathrm{~N}_{4}$ ceramics. The flexural strength

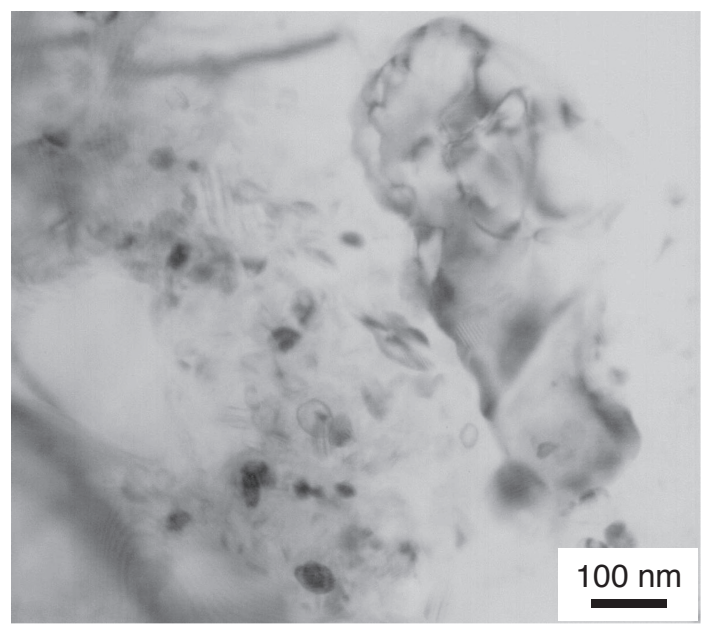

Fig. 3. TEM micrograph of dense $\mathrm{Ca}-\alpha$ SiAlON nanoceramics prepared at $1700^{\circ} \mathrm{C}$ for $20 \mathrm{~min}$ at $30 \mathrm{MPa}^{45)}$

at room temperature was $680 \mathrm{MPa}$ on average. Jones et al. ${ }^{15)-17)}$ reported that room-temperature strength of $\mathrm{Y}$ - and $\mathrm{Lu}-\alpha$ SiAlON with grain size of $1-2 \mu \mathrm{m}$ was approximately $400 \mathrm{MPa}$. The flexural strength at the high temperature of $1200^{\circ} \mathrm{C}$ had the high value of $700 \mathrm{MPa}$, which was similar to that the value at room temperature. Liu et al. ${ }^{13)}$ reported that the flexural strength of ScLu- $\alpha$ SiAlON at test temperature of $1200^{\circ} \mathrm{C}$ reached $601 \mathrm{MPa}$, which retained $92 \%$ of strength at room temperature. These results indicated that the excellent strength at both room and high temperatures could be achieved by adding $\mathrm{Ca}$ not rare-earth elements. The corrosion resistance of the $\mathrm{Ca}-\alpha$ SiAlON nanoceramics in $\mathrm{H}_{2} \mathrm{SO}_{4}$ solution was superior to that of commercial $\mathrm{Si}_{3} \mathrm{~N}_{4}$ ceramics for bearing grade. The residual glass phase in the commercial $\mathrm{Si}_{3} \mathrm{~N}_{4}$ ceramics would be easily corroded because the $\mathrm{Si}_{3} \mathrm{~N}_{4}$ ceramics are fabricated using sintering additives such as $\mathrm{Y}_{2} \mathrm{O}_{3}$ and $\mathrm{Al}_{2} \mathrm{O}_{3}$. The excellent strength at high temperature and corrosion resistance of the $\mathrm{Ca}-\alpha$ SiAlON nanoceramics would be caused by the absence of a glass phase at the grain boundary.

\section{Porous SiAION ceramics from hollow spherical Ca- $\alpha$ SiAION powder ${ }^{46)}$}

Porous $\mathrm{Ca}-\alpha$ SiAlON ceramics were fabricated by using the hollow spherical $\mathrm{Ca}-\alpha$ SiAlON powder and by maintaining their unique shape. ${ }^{46}$ ) The hollow spherical powder was sintered without using any sintering additive by SPS at $1700^{\circ} \mathrm{C}$ for 1-20 min in $\mathrm{N}_{2}$ under a uniaxial pressure of $5 \mathrm{MPa}$ at a heating rate of $100^{\circ} \mathrm{C} / \mathrm{min}$.

The open and closed porosities of the sample fabricated for 1 min by SPS were 44 and $2 \%$, respectively. The open porosity decreased with an increase in the holding time. In all samples, the phase content was almost the same as that of the $\mathrm{Ca}-\alpha$ SiAlON starting powder. In the porous $\mathrm{Ca}-\alpha$ SiAlON ceramics fabricated for $1 \mathrm{~min}$, hollow spheres with a morphology similar to that of the starting powder were observed, as shown in Fig. 4. ${ }^{46)}$ As the holding time increased, the hollow spheres gradually disappeared and the total porosity decreased. Pore-size-distribution measurements showed that the porous $\mathrm{Ca}-\alpha$ SiAlON ceramics had a large number of pores with diameters of 200$500 \mathrm{~nm}$ and a small number of pores with a diameter of approximately $10 \mathrm{~nm}$. This suggested that the morphology of the hollow spheres in the starting powder was maintained in the porous $\mathrm{Ca}-\alpha$ SiAlON ceramics with high porosity. The flexural 


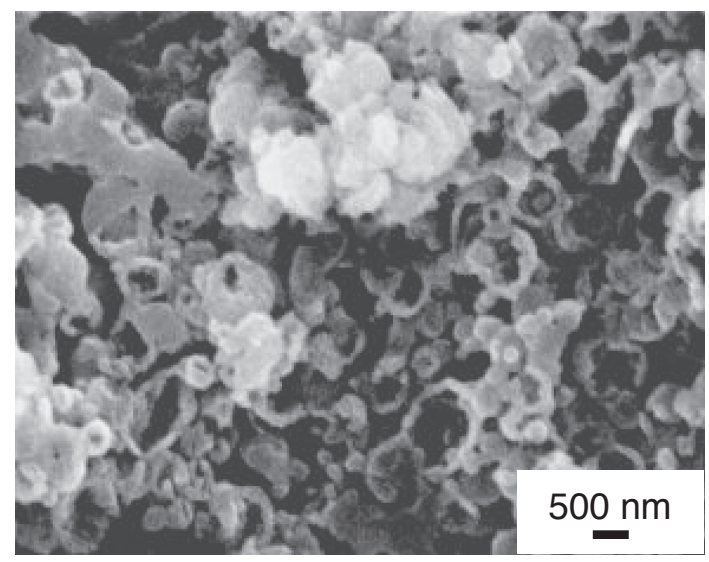

Fig. 4. SEM micrograph of the fracture surface of porous $\mathrm{Ca}-\alpha$ SiAlON ceramics prepared at $1700^{\circ} \mathrm{C}$ for $1 \mathrm{~min}$ at $5 \mathrm{MPa}^{46)}$

strength of the porous $\mathrm{Ca}-\alpha$ SiAlON ceramics decreased with an increase in the porosity. The strength of the porous $\mathrm{Ca}-\alpha$ SiAlON ceramics was higher than that of typical porous ceramics such as $\mathrm{Al}_{2} \mathrm{O}_{3}$ reported by Coble. ${ }^{47)}$ The Vickers hardness of the porous $\mathrm{Ca}-\alpha$ SiAlON ceramics decreased with increasing porosity. The hardness was higher than that of dense mullite and cordierite ceramics, and was similar to that of reaction-bonded $\mathrm{Si}_{3} \mathrm{~N}_{4}$ and porous $\mathrm{Si}_{3} \mathrm{~N}_{4}$ ceramics prepared using starch. ${ }^{48)}$ The corrosion resistance of the porous $\mathrm{Ca}-\alpha$ SiAlON ceramics in $\mathrm{H}_{2} \mathrm{SO}_{4}$ solution was better than that of commercial dense $\mathrm{Si}_{3} \mathrm{~N}_{4}$ ceramics, although the weight loss of the porous $\mathrm{Ca}-\alpha$ SiAlON ceramics in the $\mathrm{H}_{2} \mathrm{SO}_{4}$ solution was higher than that of the prepared dense $\mathrm{Ca}-\alpha$ SiAlON nanoceramics because of its high surface area.

\section{Fine-grained $\mathrm{Si}_{3} \mathrm{~N}_{4}$ ceramics with small amount of sintering additives ${ }^{49), 50)}$}

The use of a nanosized $\mathrm{Si}_{3} \mathrm{~N}_{4}$ starting powder is expected to give fine-grained $\mathrm{Si}_{3} \mathrm{~N}_{4}$ ceramics that reduce the amount of sintering additives, leading to the improvement of the mechanical properties at high temperatures and to the improvement of the corrosion and oxidation resistance. In this work, a nanosized amorphous $\mathrm{Si}_{3} \mathrm{~N}_{4}$ powder (average particle size: $80 \mathrm{~nm}$; total oxygen content: 4.8 mass $\%$ ) was first prepared by a vapor phase reaction involving $\mathrm{SiCl}_{4}$ and $\mathrm{NH}_{3}$ gases. As a reference, a submicron-sized $\alpha-\mathrm{Si}_{3} \mathrm{~N}_{4}$ powder $(\beta$-phase: $<5 \%$; average particle size: $170 \mathrm{~nm}$; total oxygen content: 1.2 mass \%) was used. The $\mathrm{Si}_{3} \mathrm{~N}_{4}$ powders were then sintered with a relatively small amount of sintering additives, 1.5 mass $\% \quad \mathrm{Y}_{2} \mathrm{O}_{3}$ and 0.5 mass $\% \mathrm{Al}_{2} \mathrm{O}_{3}$, by SPS at $1500-1700^{\circ} \mathrm{C}$ for $30 \mathrm{~min}$ and at $1800^{\circ} \mathrm{C}$ for $1 \mathrm{~min}$ at a uniaxial pressure of $30 \mathrm{MPa}$ under $\mathrm{N}_{2}{ }^{49}$

The densification of the nanosized amorphous $\mathrm{Si}_{3} \mathrm{~N}_{4}$ powder and the phase transformation to a $\beta$-phase were completed at a relatively lower temperature, i.e., $1500^{\circ} \mathrm{C}$, as compared to that in the case of the submicron-sized $\alpha-\mathrm{Si}_{3} \mathrm{~N}_{4}$ powder (Fig. 5) ${ }^{49}$ ) In the case of the submicron-sized $\alpha-\mathrm{Si}_{3} \mathrm{~N}_{4}$ powder, the relative density of the sample fabricated at $1500^{\circ} \mathrm{C}$ was approximately $60 \%$. As the temperature increased to $1800^{\circ} \mathrm{C}$, the sample had a high density of $>98 \%$. In the nanosized amorphous $\mathrm{Si}_{3} \mathrm{~N}_{4}$ powder, the density of the sample reached $95 \%$ even at $1500^{\circ} \mathrm{C}$, although the densification of the submicron-sized $\alpha-\mathrm{Si}_{3} \mathrm{~N}_{4}$ powder required a high temperature of $1800^{\circ} \mathrm{C} . \alpha-\mathrm{Si}_{3} \mathrm{~N}_{4}$ transformed into $\beta-\mathrm{Si}_{3} \mathrm{~N}_{4}$ with an increase in the density of the sample

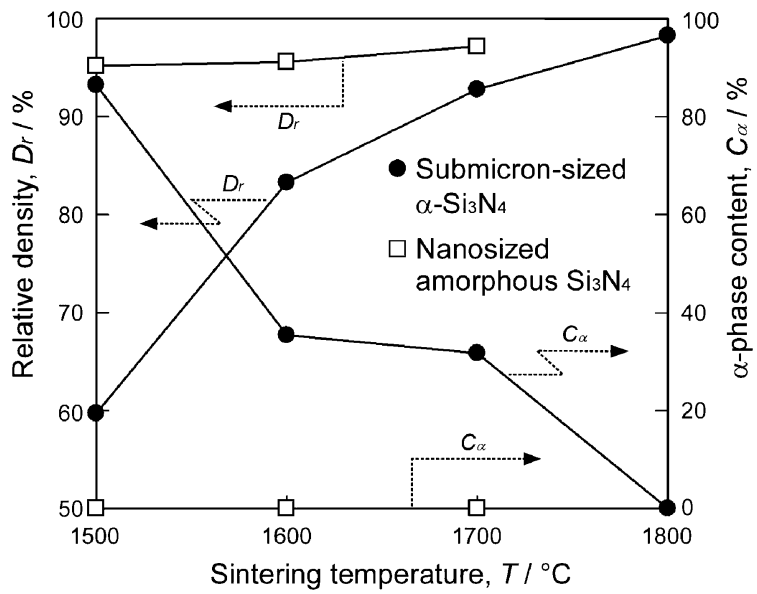

Fig. 5. Effect of sintering temperature on the relative density and $\alpha$-phase ratio of $\mathrm{Si}_{3} \mathrm{~N}_{4}$ ceramics prepared at $1500-1700^{\circ} \mathrm{C}$ for $30 \mathrm{~min}$ and at $1800^{\circ} \mathrm{C}$ for $1 \mathrm{~min}$ at $150^{\circ} \mathrm{C} / \mathrm{min}^{49)}$

when the submicron-sized $\alpha-\mathrm{Si}_{3} \mathrm{~N}_{4}$ powder was used, and only the $\beta$-phase formed at $1800^{\circ} \mathrm{C}$. In the nanosized amorphous $\mathrm{Si}_{3} \mathrm{~N}_{4}$ powder, the amorphous phase directly transformed into the crystalline $\beta$-phase, and only the $\beta$-phase existed even at $1500^{\circ} \mathrm{C}$. The high sinterability of the nanosized amorphous $\mathrm{Si}_{3} \mathrm{~N}_{4}$ powder could result from the small particle size and the high total oxygen content of the nanosized amorphous $\mathrm{Si}_{3} \mathrm{~N}_{4}$ powder. The phase transformation from $\alpha$ - to $\beta-\mathrm{Si}_{3} \mathrm{~N}_{4}$ is mainly dependent on the densification. ${ }^{51)}$ Consequently, because the densification of the nanosized amorphous $\mathrm{Si}_{3} \mathrm{~N}_{4}$ powder was achieved at a temperature lower than that for the submicron-sized $\alpha-\mathrm{Si}_{3} \mathrm{~N}_{4}$ powder, the transformation to the $\beta$-phase would be completed at a low temperature.

The $\mathrm{Si}_{3} \mathrm{~N}_{4}$ body obtained from the nanosized amorphous $\mathrm{Si}_{3} \mathrm{~N}_{4}$ powder was composed of finer equiaxed and elongated grains, compared to that obtained from the submicronsized $\alpha-\mathrm{Si}_{3} \mathrm{~N}_{4}$ powder, at $1700^{\circ} \mathrm{C}$ for $30 \mathrm{~min}$ at $150^{\circ} \mathrm{C} / \mathrm{min}$ (Fig. 6). ${ }^{49)}$ In addition, residual pores were observed in the $\mathrm{Si}_{3} \mathrm{~N}_{4}$ body obtained from the submicron-sized $\alpha-\mathrm{Si}_{3} \mathrm{~N}_{4}$ powder. Therefore, the grain growth was inhibited during sintering, leading to the production of fine-grained $\mathrm{Si}_{3} \mathrm{~N}_{4}$ ceramics. The densification of liquid-phase sintered $\mathrm{Si}_{3} \mathrm{~N}_{4}$ using conventional sintering techniques such as gas-pressure sintering and hotpressing generally required the amount of sintering additives of 5-10 mass \%. ${ }^{51), 52)}$

$\mathrm{Si}_{2} \mathrm{~N}_{2} \mathrm{O}$ formed as a secondary phase for a long sintering time at $150^{\circ} \mathrm{C} / \mathrm{min}$ at $1500-1700^{\circ} \mathrm{C}$ for a holding time of $30 \mathrm{~min}$ when the nanosized amorphous $\mathrm{Si}_{3} \mathrm{~N}_{4}$ powder was used. When rapid sintering was performed at $300^{\circ} \mathrm{C} / \mathrm{min}$ at $1800^{\circ} \mathrm{C}$ for $1 \mathrm{~min}$, dense $\beta-\mathrm{Si}_{3} \mathrm{~N}_{4}$ ceramics consisting of equiaxed grains with an average size of $300 \mathrm{~nm}$ were fabricated without the formation of $\mathrm{Si}_{2} \mathrm{~N}_{2} \mathrm{O}$.

\section{Fine-grained $\mathrm{SiC}$ ceramics with AIN sintering additive ${ }^{53)-55)}$}

The SiC ceramics prepared through liquid-phase sintering with AIN and rare-earth oxides have showed an improvement in the high-temperature strength and oxidation resistance. ${ }^{56), 57)}$ Some researchers have reported that the improvement of these properties is due to a decrease in the amount of glass phase in the grain boundary; the decrease results from the formation of a $\mathrm{SiC}-\mathrm{AlN}$ solid solution and an increase in the heat resistance of 

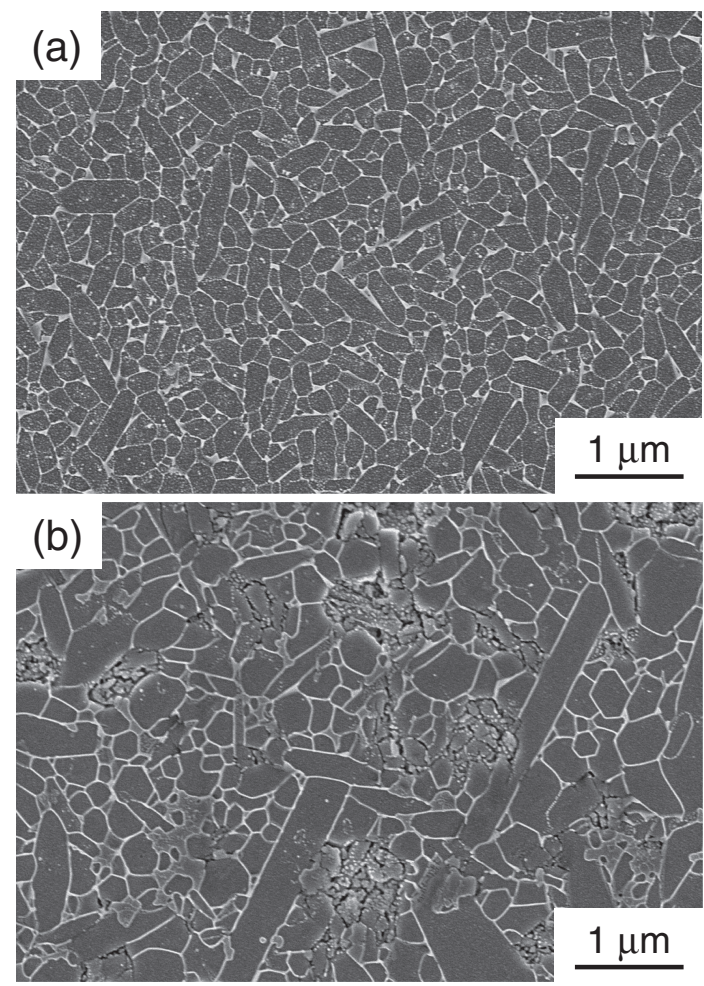

Fig. 6. SEM micrographs of the etched surfaces of $\mathrm{Si}_{3} \mathrm{~N}_{4}$ ceramics prepared at $1700^{\circ} \mathrm{C}$ for $30 \mathrm{~min}$ at $150^{\circ} \mathrm{C} / \mathrm{min}$ using nanosized amorphous $\mathrm{Si}_{3} \mathrm{~N}_{4}$ (a) and submicron-sized $\alpha-\mathrm{Si}_{3} \mathrm{~N}_{4}$ powders (b). ${ }^{49)}$

the glass phase because of the addition of AlN and rare-earth oxide additives. ${ }^{58), 59)}$ In this work, $\mathrm{SiC}$ ceramics were prepared from submicron- and nano-sized $\beta$-SiC powders with $10 \mathrm{vol} \%$ AlN and $\mathrm{Y}_{2} \mathrm{O}_{3}$ sintering additives by SPS.

In the case of the submicron-sized $\beta$-SiC starting powder, the relative density of $\mathrm{SiC}$ sintered bodies was greater than $95 \%$ at $1900^{\circ} \mathrm{C}$ for $10 \mathrm{~min}$ in $\mathrm{N}_{2}$ at a pressure of $30 \mathrm{MPa}$. The density increased with increasing AlN additive content for $10 \mathrm{vol} \%$ AlN- $\mathrm{Y}_{2} \mathrm{O}_{3}$ additives. The crystalline phase of the $\mathrm{SiC}$ bodies was mainly $3 \mathrm{C}(\beta-\mathrm{SiC})$. A $2 \mathrm{H}$ phase, which is assigned to $\mathrm{AlN}$ or one of $\alpha$-SiC phases, was detected when a large amount of AlN additive was used. In contrast, a $4 \mathrm{H}-\mathrm{SiC}(\alpha-\mathrm{SiC})$ phase was identified when $\mathrm{Al}_{2} \mathrm{O}_{3}$ was used as the sintering additive. Because AlN has hexagonal crystal system and is soluble in $2 \mathrm{H}-\mathrm{SiC}$, AlN can form a solid solution with $2 \mathrm{H}-\mathrm{SiC}{ }^{60)}$ Hence, the peak of the $2 \mathrm{H}$ phase observed in this work may suggest the existence of a $\mathrm{SiC}-\mathrm{AlN}$ solid solution and/or AlN remaining in the $\mathrm{SiC}$ bodies sintered with the AlN additive. The size of the $\mathrm{SiC}$ grains decreased with an increase in the amount of the AlN additive (Fig. 7). ${ }^{53)}$ The grain morphology changed from globular to angular when the amount of AlN additive was increased. The size and morphology of the $\mathrm{SiC}$ grains prepared at an additive composition of $95 \mathrm{~mol} \% \mathrm{AlN}$ and $5 \mathrm{~mol} \% \mathrm{Y}_{2} \mathrm{O}_{3}$ were almost the same as those of the $\mathrm{SiC}$ starting powder, suggesting that the grain growth was inhibited during the liquid-phase sintering. On the other hand, in a dense $\mathrm{SiC}$ body sintered with 2 mass $\% \mathrm{Al}_{2} \mathrm{O}_{3}$ additive, grain growth and elongated grains were observed. The flexural strength of the $\mathrm{SiC}$ sintered bodies increased with the AlN additive amount. The strength of the sample obtained at $95 \mathrm{~mol} \%$ AlN and $5 \mathrm{~mol} \% \quad \mathrm{Y}_{2} \mathrm{O}_{3}$ reached a high value of $1150 \mathrm{MPa}$. In the sample sintered with 2 mass $\% \mathrm{Al}_{2} \mathrm{O}_{3}$ additive, the strength was $780 \mathrm{MPa}$.

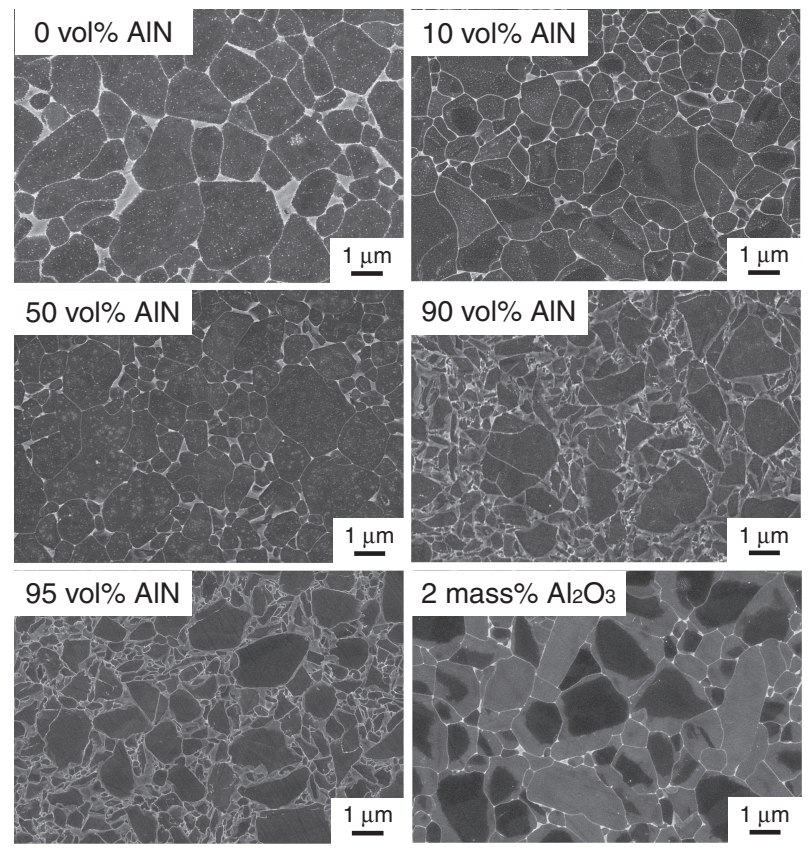

Fig. 7. SEM micrographs of the etched surfaces of $\mathrm{SiC}$ ceramics prepared with different compositions of $\mathrm{AlN}-\mathrm{Y}_{2} \mathrm{O}_{3}$ additives and with 2 mass $\% \mathrm{Al}_{2} \mathrm{O}_{3}$ additive at $1900^{\circ} \mathrm{C}$ for $10 \mathrm{~min}^{53}$ )

By using nanosized $\beta$-SiC starting powder with a particle diameter of $40 \mathrm{~nm}, \mathrm{SiC}$ ceramics were prepared by SPS; AlN$\mathrm{Y}_{2} \mathrm{O}_{3}$ additives were used in the preparation. ${ }^{54)}$ As a result, the behaviors of the densification, phase transformation, and grain morphology were similar to those of $\mathrm{SiC}$ ceramics prepared using the submicron-sized $\beta$-SiC powder. Fully dense $\mathrm{SiC}$ ceramics prepared with $10 \mathrm{vol} \%$ additives consisting of $90 \mathrm{~mol} \% \mathrm{AlN}$ and $10 \mathrm{~mol} \% \mathrm{Y}_{2} \mathrm{O}_{3}$ had the smallest grain size of $150 \mathrm{~nm}$. Furthermore, nanostructured $\mathrm{SiC}$ ceramics consisting of equiaxed grains (diameter: $70 \mathrm{~nm}$ ) were fabricated by using AlN-rich additives with a 10 vol $\%$ additive containing $95 \mathrm{~mol} \%$ AlN and $5 \mathrm{~mol} \%$ $\mathrm{Y}_{2} \mathrm{O}_{3}$ and by short-time sintering by SPS at $1900^{\circ} \mathrm{C}$ for $5 \mathrm{~min}$ at the heating rate of $100^{\circ} \mathrm{C} / \mathrm{min}^{55)}$

\section{Cubic-BN-dispersed ceramic composites ${ }^{61)-66)}$}

Cubic-BN (cBN)-dispersed ceramic composites were fabricated at a moderate pressure of $100 \mathrm{MPa}$ at various sintering temperatures by SPS, and the densification, phase transformation, microstructure, and mechanical properties of the composites were investigated.

$\mathrm{Al}_{2} \mathrm{O}_{3}-\mathrm{cBN}$ composites were prepared from $\mathrm{Al}_{2} \mathrm{O}_{3}$ and $\mathrm{cBN}$ powders by SPS at $1200-1600^{\circ} \mathrm{C}$ for $10 \mathrm{~min}$ at a pressure of $100 \mathrm{MPa}{ }^{61)} \mathrm{Al}_{2} \mathrm{O}_{3}-\mathrm{cBN}$ composites originally containing 10 $20 \mathrm{vol} \% \mathrm{cBN}$ with a relative density greater than $98 \%$ were obtained at $1300^{\circ} \mathrm{C}$ without a phase transformation of $\mathrm{cBN}$ to hexagonal BN (hBN) (Fig. 8). ${ }^{61)}$ The phase transformation of cBN in the $\mathrm{Al}_{2} \mathrm{O}_{3}-\mathrm{cBN}$ composites was more likely than in the cBN body. The addition of $\mathrm{cBN}$ to $\mathrm{Al}_{2} \mathrm{O}_{3}$ inhibited the grain growth of $\mathrm{Al}_{2} \mathrm{O}_{3}$ in the $\mathrm{Al}_{2} \mathrm{O}_{3}-\mathrm{cBN}$ composites. The Vickers hardness of the dense $\mathrm{Al}_{2} \mathrm{O}_{3}-\mathrm{cBN}$ composites originally containing $10-20 \mathrm{vol} \% \mathrm{cBN}$ prepared at $1300^{\circ} \mathrm{C}$ reached a maximum value of $26 \mathrm{GPa}$. In cBN-TiN-Al composites, the hardness increased with an increase in $\mathrm{cBN}$ content and the hardness of the composite containing $75 \mathrm{vol} \% \mathrm{cBN}$ was $30 \mathrm{GPa}^{67)} \mathrm{In} \mathrm{WC}-$ Co-cBN composites prepared by hot isostatic pressing, the hardness of the composites reached $25 \mathrm{GPa}^{68)}$ Moreover, in WC- 


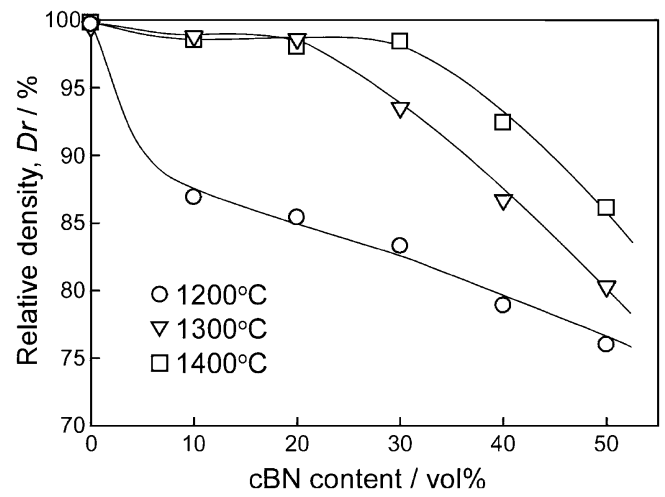

Fig. 8. Effect of $\mathrm{cBN}$ content on the relative density of $\mathrm{Al}_{2} \mathrm{O}_{3}$ bodies and $\mathrm{Al}_{2} \mathrm{O}_{3}-\mathrm{BN}$ composites prepared at $1200-1400^{\circ} \mathrm{C}$ for 10 min. $^{61)}$

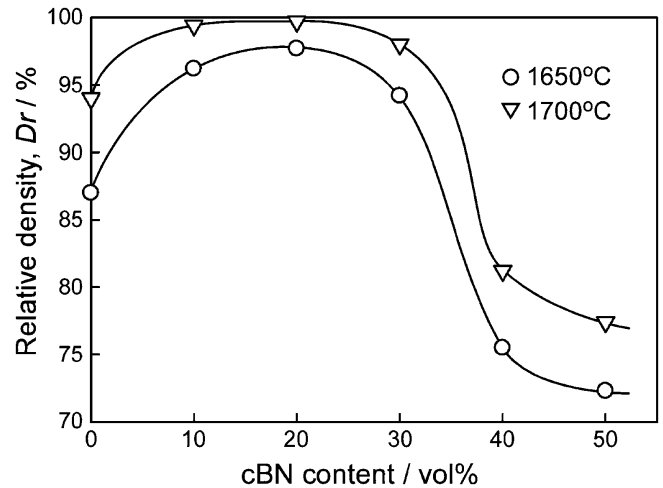

Fig. 9. Effect of $\mathrm{cBN}$ content on the relative density of $\beta \mathrm{SiAlON}$ bodies and $\beta$ SiAlON-BN composites prepared at 1650 and $1700^{\circ} \mathrm{C}$ without a holding time. ${ }^{63)}$

Co-cBN composites prepared by SPS, the addition of $\mathrm{cBN}$ to

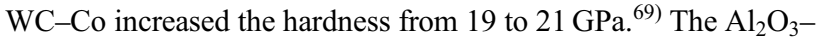
cBN composite originally containing $20 \mathrm{vol} \% \mathrm{cBN}$ prepared at $1300^{\circ} \mathrm{C}$ had the highest fracture toughness, $4.1 \mathrm{MPa} \cdot \mathrm{m}^{1 / 2}$. In addition, the Vickers hardness of the $\mathrm{Al}_{2} \mathrm{O}_{3}-\mathrm{cBN}$ composites was characterized at indentation loads from 0.098 to $19.6 \mathrm{~N}^{62)}$ The hardness of the $\mathrm{BN}$ grains in the $\mathrm{Al}_{2} \mathrm{O}_{3}-\mathrm{BN}$ composite prepared at $1300^{\circ} \mathrm{C}$ without the transformation of the $\mathrm{cBN}$ to the $\mathrm{hBN}$ phase was $59 \mathrm{GPa}$ at the indentation load of $0.098 \mathrm{~N}$. The hardness of the $\mathrm{Al}_{2} \mathrm{O}_{3}$ matrix in the $\mathrm{Al}_{2} \mathrm{O}_{3}-\mathrm{BN}$ composites originally containing $10-30 \mathrm{vol} \% \mathrm{cBN}$ prepared at 1300 $1400^{\circ} \mathrm{C}$ was approximately $25 \mathrm{GPa}$ at $0.098 \mathrm{~N}$, which was higher than that of the monolithic $\mathrm{Al}_{2} \mathrm{O}_{3}$ bodies prepared at the same temperatures. The hardness of the $\mathrm{Al}_{2} \mathrm{O}_{3}$ matrix in the $\mathrm{Al}_{2} \mathrm{O}_{3}-\mathrm{BN}$ composites decreased with increasing sintering temperature.

$\beta$ SiAlON-cBN composites were prepared from $\beta$ SiAlON and cBN powders at $1600-1900^{\circ} \mathrm{C}$ without a holding time. ${ }^{63)}$ The finishing temperature of shrinkage of the $\beta$ SiAlON-BN composites originally containing $10-30 \mathrm{vol} \% \mathrm{cBN}$ was lower than that of monolithic $\beta$ SiAlON. The relative density of the $\beta$ SiAlONBN composites increased when $10-30$ vol $\% \mathrm{cBN}$ was added to $\beta$ SiAlON (Fig. 9), ${ }^{63)}$ although the addition of $\mathrm{cBN}$ to $\mathrm{Al}_{2} \mathrm{O}_{3}$ led to a decrease in relative density of the $\mathrm{Al}_{2} \mathrm{O}_{3}-\mathrm{CBN}$ composites. The densification of the $\beta$ SiAlON-BN composite originally containing more than $40 \mathrm{vol} \% \mathrm{cBN}$ was inhibited. Martínez and Echeberria ${ }^{68)}$ studied the densification behavior of $\mathrm{WC}-\mathrm{Co}-\mathrm{cBN}$ composites with the addition of $\mathrm{cBN}$ up to $50 \mathrm{vol} \%$ and found the densification of $\mathrm{WC}-\mathrm{Co}$ was significantly prevented by the addition of cBN. Martín et al. ${ }^{70)}$ also reported the reduction of densification of $\mathrm{cBN}-\mathrm{Cu}-\mathrm{Ti}$ composites with an increase in the $\mathrm{cBN}$ content. The phase transformation of $\mathrm{cBN}$ to $\mathrm{hBN}$ in the $\beta$ SiAlON-BN composite was suppressed to a greater extent than in the $\mathrm{cBN}$ body. When $10 \mathrm{vol} \% \mathrm{cBN}$ was added to $\beta \mathrm{SiAlON}$, the Vickers hardness of the $\beta$ SiAlON-BN composite prepared at 1650 and $1700^{\circ} \mathrm{C}$ increased from 9 to $14 \mathrm{GPa}$ and 13 to $16 \mathrm{GPa}$, respectively. The $\mathrm{cBN}$ phase transformed into $\mathrm{hBN}$, and the hardness decreased with increasing holding time. ${ }^{64)}$ The phase transformation of $\mathrm{cBN}$ was retarded by increasing the heating rate, resulting in increased hardness of the $\beta \mathrm{SiAlON}-\mathrm{BN}$ composite.

Dense TiN-cBN and mullite-cBN composites without the phase transformation from $\mathrm{cBN}$ to low-hardness $\mathrm{hBN}$ were also obtained under a moderate pressure of $100 \mathrm{MPa}$ by SPS. ${ }^{65), 66)}$

\section{Summary}

Hollow spherical $\mathrm{Ca}-\alpha$ SiAlON powders composed of nanosized particles were successfully synthesized from a relatively inexpensive starting material such as a $\mathrm{SiO}_{2}-\mathrm{Al}_{2} \mathrm{O}_{3}-\mathrm{CaCO}_{3}$ powder mixture by using a convenient production process involving carbothermal reduction-nitridation. Using the nanosized $\mathrm{Ca}-\alpha$ SiAlON powder, dense $\mathrm{Ca}-\alpha$ SiAlON nanoceramics with high hardness, high corrosion resistance, and excellent strength at high temperatures were obtained by using the SPS technique; no sintering additive was used. Porous $\mathrm{Ca}-\alpha$ SiAlON ceramics were also obtained, without using a sintering additive, from the hollow spherical $\mathrm{Ca}-\alpha$ SiAlON powders by SPS. Ultrafine-grained $\mathrm{Si}_{3} \mathrm{~N}_{4}$ and $\mathrm{SiC}$ ceramics were prepared from fine-grained starting powders by rapid sintering using the SPS technique. The densification of cBN-dispersed ceramic composites, such as $\mathrm{Al}_{2} \mathrm{O}_{3}-\mathrm{cBN}, \beta$ SiAlON-cBN, TiN$\mathrm{cBN}$, and mullite-cBN, was achieved without the phase transformation of $\mathrm{cBN}$ to low-hardness $\mathrm{hBN}$, at a moderate pressure by SPS.

Acknowledgements The author thanks Professors Katsutoshi Komeya, Takeshi Meguro and Junichi Tatami of Yokohama National University, Professor Junichi Hojo of Kyushu University, Professor Takashi Goto of Tohoku University, and Professor Yi-Bing Cheng of Monash University, Australia, for their kind support during the present work and for their helpful suggestions and comments. This study was funded by a Grant-in-Aid for Japan Society for the Promotion of Science (JSPS) Fellows (Nos. 00055 and 07570), a Grant-in-Aid for Young Scientists (Start-up) (No. 18860009), and in part by the Research for the Future Program of JSPS under the Project 'Next-Generation Process Technologies', and the New Energy and Industrial Technology Development Organization (NEDO) as part of Synergy Ceramics Project under the Industrial Science and Technology Frontier (ISTF) Program promoted by the National Institute of Advanced Industrial Science and Technology (AIST), Ministry of Economy, Trade and Industry (METI), Japan. This study was also supported by the Asian CORE Program and the Global COE Program 'Materials Integration, Tohoku University', of the Ministry of Education, Culture, Sports, Science and Technology (MEXT), Japan and the Rare Metal Substitution Materials Development Project of NEDO. The author also appreciates the financial support extended by Mitsubishi Materials Corporation.

References

1) S. Hampshire, H. K. Park, D. P. Thompson and K. H. Jack, Nature, 274, 880-882 (1978).

2) K. H. Jack, J. Mater. Sci., 11, 1135-1158 (1976). 
3) R. Shuba and I. W. Chen, J. Am. Ceram. Soc., 89, 1065-1071 (2006).

4) J. W. T. van Rutten, R. A. Terpstra, J. C. T. Heijde, H. T. Hintzen and R. Metselaar, J. Eur. Ceram. Soc., 15, 599-604 (1995).

5) M. Mitomo, M. Takeuchi and M. Ohmasa, Ceram. Int., 14, 43-48 (1988)

6) J. Y. Qiu, J. Tatami, C. Zhang, K. Komeya, T. Meguro and Y.-B. Cheng, J. Eur. Ceram. Soc., 22, 2989-2996 (2002).

7) C. Zhang, K. Komeya, J. Tatami, T. Meguro and Y.-B. Cheng, J. Eur. Ceram. Soc., 20, 1809-1814 (2000)

8) T. Ekström, Z.-J. Shen, K. J. D. MacKenzie, I. W. M. Brown and G. V. White, J. Mater. Chem., 8, 977-983 (1998).

9) Y.-B. Cheng, M. R. Terner, W. W. Chen and P. L. Wang, Key Eng. Mater., 264-268, 781-786 (2004).

10) M. R. Terner and Y.-B. Cheng, Proceedings Int. Conf. Adv. Mat. Proc 3, Melbourne 2004, 50-51 (2004).

11) T. Wakihara, S. Kamiwaki, J. Tatami, K. Komeya and T. Meguro, J. Ceram. Soc. Japan, 115, 294-296 (2007).

12) C. L. Hewett, Y.-B. Cheng, B. C. Muddle and M. B. Trigg, J. Eur. Ceram. Soc., 18, 417-427 (1998).

13) C. Liu, F. Ye, L. Liu and Y. Zhou, Scr. Mater., 60, 929-932 (2009).

14) J. Yu, H. Du, R. Shuba and I.-W. Chen, J. Mater. Sci., 39, 4855-4860 (2004).

15) M. I. Jones, H. Hyuga, K. Hirao and Y. Yamauchi, J. Am. Ceram. Soc., 87, 714-716 (2004).

16) M. I. Jones, K. Hirao, H. Hyuga, Y. Yamauchi and S. Kanzaki, J. Eur. Ceram. Soc., 23, 1743-1750 (2003).

17) M. I. Jones, H. Hyuga and K. Hirao, J. Am. Ceram. Soc., 86, 520-522 (2003).

18) J. H. Zhang, P. L. Wang, J. Zhang and D. S. Yan, J. Mater. Sci., 37, 1407-1412 (2002).

19) Y. Ukyo, J. Mater. Sci., 32, 5483-5489 (1997).

20) S. Prochazka, in "Special Ceramics 6" Ed. by P. Popper, British Ceramic Research Association, Stoke-on-Trent, U.K. (1975) pp. 171-181.

21) M. Omori and H. Takei, J. Am. Ceram. Soc., 65, C-92 (1982).

22) N. P. Padture, J. Am. Ceram. Soc., 77, 519-523 (1994).

23) M. Keppeler, H.-G. Reichert, J. M. Broadley, G. Thurn, I. Wiedmann and F. Aldinger, J. Eur. Ceram. Soc., 18, 521-526 (1998).

24) R. H. Wentorf, R. C. DeVries and F. P. Bundy, Science, 208, 873-880 (1980).

25) V. L. Solozhenko, V. Z. Turkevich and W. B. Holzapfel, J. Phys. Chem. B, 103, 2903-2905 (1999).

26) F. R. Corrigan and F. P. Bundy, J. Chem. Phys., 63, 3812-3820 (1975).

27) F. P. Bundy and R. H. Wentorf, Jr., J. Chem. Phys., 38, 11441149 (1963).

28) P. Klimczyk, E. Benko, K. Lawniczak-Jablonska, E. Piskorska, M. Heinonen, A. Ormaniec, W. Gorczynska-Zawislan and V. S. Urbanovich, J. Alloys Compd., 382, 195-205 (2004).

29) X. Z. Rong and T. Yano, J. Mater. Sci., 39, 4705-4710 (2004).

30) X. Z. Rong, T. Tsurumi, O. Fukunaga and T. Yano, Diamond Relat. Mater., 11, 280-286 (2002).

31) X. Z. Rong and O. Fukunaga, Advanced Materials '93, I/B, Ed. by M. Homma et al., Elsevier Science B.V., Trans. Mater. Res. Soc. Jpn., 14B, (1994) pp. 1455-1458.

32) V. Martínez and J. Echeberria, J. Am. Ceram. Soc., 90, 415424 (2007)

33) M. Tokita, J. Soc. Powder Technol. Jpn., 30, 790-804 (1993).

34) Y. Zhou, K. Hirao, Y. Yamauchi and S. Kanzaki, J. Eur. Ceram. Soc., 24, 3465-3470 (2004).

35) M. Suganuma, Y. Kitagawa, S. Wada and N. Murayama, J. Am. Ceram. Soc., 86, 387-394 (2003).

36) Y. Zhou, K. Hirao, M. Toriyama and H. Tanaka, J. Am. Ceram. Soc., 83, 654-656 (2000).
37) J. R. Groza, J. D. Curtis and M. Krämer, J. Am. Ceram. Soc., 83, 1281-1283 (2000).

38) J. A. Schneider, S. H. Risbud and A. K. Mukherjee, J. Mater. Res., 11, 358-362 (1996).

39) T. Nishimura, M. Mitomo, H. Hirotsuru and M. Kawahara, J. Mater. Sci. Lett., 14, 1046-1047 (1995).

40) K. Komeya, C. Zhang, M. Hotta, J. Tatami, T. Meguro and Y.-B. Cheng, J. Am. Ceram. Soc., 83, 995-997 (2000).

41) M. Hotta, J. Tatami, K. Komeya, T. Meguro and Y.-B. Cheng, J. Ceram. Soc. Japan, 118, 827-829 (2010).

42) M. Hotta, J. Tatami, K. Komeya, C. Zhang, T. Meguro, M. R. Terner and Y.-B. Cheng, J. Am. Ceram. Soc., 91, 860-864 (2008).

43) M. Hotta, J. Tatami, C. Zhang, K. Komeya, T. Meguro, M. R. Terner and Y.-B. Cheng, Ceram. Int., 36, 1553-1559 (2010).

44) M. Hotta, J. Hojo, K. Komeya, J. Tatami, T. Meguro, H. Masuda, K. Morinaga and Y.-B. Cheng, Mater. Lett., 65, 116118 (2011).

45) J. Tatami, M. Iguchi, M. Hotta, C. Zhang, K. Komeya, T Meguro, M. Omori, T. Hirai, M. E. Brito and Y.-B. Cheng, Key Eng. Mater., 237, 105-110 (2003).

46) J. Tatami, T. Ohta, C. Zhang, M. Hotta, K. Komeya, T. Meguro, M. Omori and T. Hirai, Ceram. Trans., 142, 77-87 (2003).

47) R. L. Coble and W. D. Kingery, J. Am. Ceram. Soc., 39, 377385 (1956).

48) Handbook of Ceramics [2nd Edition], Ed. by Ceramic Society of Japan, Gihodo, Tokyo (2002).

49) M. Hotta, T. Shinoura, N. Enomoto and J. Hojo, J. Am. Ceram. Soc., 93, 1544-1546 (2010)

50) M. Hotta and J. Hojo, J. Ceram. Soc. Japan, 117, 1302-1305 (2009).

51) L. J. Bowen, R. J. Weston, T. G. Carruthers and R. J. Brook, J. Mater. Sci., 13, 341-350 (1978).

52) J. Szépvölgyi and I. Mohai, Ceram. Int., 25, 717-721 (1999).

53) M. Hotta and J. Hojo, J. Ceram. Soc. Japan, 117, 1009-1012 (2009).

54) M. Hotta and J. Hojo, J. Eur. Ceram. Soc., 30, 2117-2122 (2010).

55) M. Hotta, H. Kita and J. Hojo, J. Ceram. Soc. Japan, 119, 129132 (2011)

56) M. Keppeler, H.-G. Reichert, J. M. Broadley, G. Thurn, I. Wiedmann and F. Aldinger, J. Eur. Ceram. Soc., 18, 521-526 (1998).

57) Y.-W. Kim, M. Mitomo and T. Nishimura, J. Am. Ceram. Soc., 85, 1007-1009 (2002).

58) Y.-W. Kim, M. Mitomo and T. Nishimura, J. Am. Ceram. Soc., 84, 2060-2064 (2001)

59) K. Suzuki and M. Sasaki, Ceram. Int., 31, 749-755 (2005).

60) A. Zangvil and R. Ruh, J. Am. Ceram. Soc., 71, 884-890 (1988).

61) M. Hotta and T. Goto, J. Ceram. Soc. Japan, 116, 744-748 (2008).

62) M. Hotta and T. Goto, Ceram. Int., 37, 1453-1457 (2011).

63) M. Hotta and T. Goto, J. Am. Ceram. Soc., 92, 1684-1690 (2009).

64) M. Hotta and T. Goto, Ceram. Int., 37, 521-524 (2011).

65) M. Hotta and T. Goto, J. Ceram. Soc. Japan, 118, 137-140 (2010).

66) M. Hotta and T. Goto, J. Ceram. Soc. Japan, 118, 157-160 (2010).

67) X. Z. Rong and O. Fukunaga, Advanced Materials '93, I/B, Ed. by M. Homma et al., Elsevier Science B.V., Trans. Mater. Res. Soc. Jpn., 14B, pp. 1455-1458 (1994).

68) V. Martínez and J. Echeberria, J. Am. Ceram. Soc., 90, 415424 (2007).

69) B. Yaman and H. Mandal, Mater. Lett., 63, 1041-1043 (2009).

70) J. Martín, J. García, R. Gonzáles, I. Iturriza and F. Castro, Advances in Powder Metallurgy and Particulate Materials, Washington MPIF, 11, (1996) pp. 209-220. 


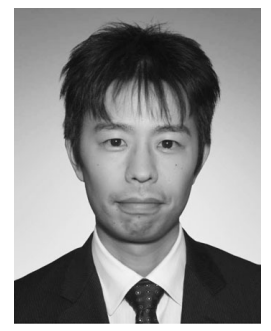

Mikinori Hotta is a Research Scientist in the Ceramic Mechanical Parts Processing Group, Advanced Manufacturing Research Institute, National Institute of Advanced Industrial Science and Technology (AIST), Japan. He graduated from the Kanagawa Institute of Technology in 1998, received a master's degree from Yokohama National University in 2000, and received his doctoral degree from Yokohama National University in 2003. He worked as a JSPS Postdoctoral Research Fellow at Kyushu University from 2003 to 2006, as a Research Associate at Tohoku University from 2006 to 2009, and as a Research Fellow at Osaka University from 2009 to 2010. Since 2010, he has been working as a Research Scientist at the AIST. His current research interests are ceramic processing and the development of large-scale and complex-shaped ceramic parts for use as industrial components to contribute to energy saving in manufacturing plants. 